\title{
Bringing radio into America's homes: marketing new technology in the Great Depression
}

Article

Accepted Version

Scott, P. and Walker, J. T. (2016) Bringing radio into America's homes: marketing new technology in the Great Depression. Business History Review, 90 (2). pp. 251-276. ISSN 2044768X doi: https://doi.org/10.1017/S0007680516000349 Available at https://centaur.reading.ac.uk/48682/

It is advisable to refer to the publisher's version if you intend to cite from the work. See Guidance on citing.

To link to this article DOI: http://dx.doi.org/10.1017/S0007680516000349

Publisher: Cambridge University Press

All outputs in CentAUR are protected by Intellectual Property Rights law, including copyright law. Copyright and IPR is retained by the creators or other copyright holders. Terms and conditions for use of this material are defined in the End User Agreement.

www.reading.ac.uk/centaur 
Central Archive at the University of Reading

Reading's research outputs online 
Peter Scott and James T. Walker

\title{
Bringing Entertainment into America's homes: Marketing Radios in an Era of Rapid Technological Change
}

\begin{abstract}
We examine the early marketing and distribution of entertainment radio sets. Manufacturers used distribution networks to both maximise profits and create barriers to entry. Lacking the market power of auto manufacturers, they developed cooperative strategies with authorised distributors and dealers. Dealers often complained about the costly activities manufacturers required of them. However, these underpinned the dominant quality and branding competition model of the 1920s, while the Depression era switch to a simpler radio format, sold on price, proved catastrophic for the specialist retailer.
\end{abstract}

\section{Acknowledgements}

We thank the Hagley Museum Library; Library of Congress; McLean County Museum of History; Peter Burton; and Smithsonian National Museum of American History, Lemelson Center Archives; for generous assistance. Thanks are also due to Harold Cones and Dan Nunan, and participants at the 2014 Association of Business Historians and Economic History Society conferences, and the Henley Business School IBS seminar series, for their comments, and also to an editor of the journal for detailed and helpful input. Any errors are our own. 
Together with the automobile, entertainment radio was the key transformative communications technology of the 1920s. Radio broadcasting had wide-reaching impacts: unifying an ethnically and culturally diverse nation, reducing the isolation of rural and smalltown America, introducing regional music styles to a national audience, and bringing a new, intrusive, and inescapable form of advertising into people's homes. Radio even had a major impact in reducing linguistic diversity, establishing 'broadcast English' as the new national popular norm. ${ }^{i}$ Even compared to earlier communications technologies - the telegraph, railroad, and telephone - its impact was dramatic; both in terms of the broad range of information and entertainment it instantly conveyed and its extremely rapid diffusion. ${ }^{\text {ii }}$

To meet the explosive demand for radio, manufacturers required effective downstream distribution systems. Existing high-ticket consumer goods offered a variety of models. Singer marketed their sewing machines principally through their own retail outlets. ${ }^{\text {iii }}$ Meanwhile auto producers assumed considerable control over franchised dealership networks. Radio appeared to have stronger parallels with three novel labour-saving appliances being introduced to American homes via aggressive salesmanship - vacuum cleaners, washing machines, and refrigerators. These were characterised by high prices, a consequent reliance of time-payment plans, and inter-firm competition based on intensive promotion, branding, and quality, rather than price.

In contrast to these 'white goods', which faced very strong initial consumer resistance and inertia, necessitating 'push selling' by door-to-door salesmen trained and supervised by the manufacturer, radio instantly found a ready market. Yet set-makers faced greater business risks than white goods producers, owing to the lack of strong technical economies of scale in production, the consequent ease of entry to the sector, and rapid and unpredictable technical obsolescence. They thus sought to market their products co-operatively with independent distributors (wholesalers) and dealers (retailers), who were incentivised to conform to their marketing policy and promote their brand over competitors.

Dealers increasingly perceived that the level, and mix, of marketing activities advocated by manufacturers was not optimal from their perspective. Door-to-door canvassing presented a particular grievance. Many retailers found that this acted to boost sales, but not profits, while incurring significant managerial problems in monitoring and motivating salesmen. Our analysis confirms dealers' perceptions that, by the late 1920s, door-to-door 
sales were of much greater benefit to the manufacturer than the dealer. However, this nevertheless provided dealers with some measure of protection from competition. During the depression manufacturers' control over distribution networks broke down and dealers (desperate to survive in a market overloaded with surplus stock at distress prices), embraced a new, radically cheaper, radio set format, the midget, produced by firms outside the mainstream industry. By doing so they undermined their key differentiating advantages compared to general retailers and precipitated the rapid decline of the specialist radio dealer.

\section{Manufacturers' promotional and distribution strategies}

The launch of entertainment radio at the start of the 1920s was followed by a boom in equipment sales, unprecedented for any high-ticket household durable. The proportion of American homes with radios rose from less than 1 per cent in 1922 to 16.0 per cent in 1926 , 45.8 per cent in 1930 and 67.3 per cent in 1935 - by which time a significant number owned more than one set. ${ }^{\text {iv }}$ Fears that the growth of broadcasting would not keep pace with radio set demand proved unfounded. During 1922 alone the number of licensed stations rose from 28 to 570. ${ }^{\mathrm{v}}$ These were established by a variety of organizations, including newspapers, educational institutions, retailers, and municipalities. Start-up costs were low, as stations generally broadcast over relatively short distances and used either amateur performers or professionals who could be persuaded to appear for free. ${ }^{\mathrm{vi}}$

Radio equipment manufacturers and dealers played a key pioneering role in broadcasting, representing the largest single category of station owner by $1923 .{ }^{\text {vii }}$ Some also took the lead in developing regular national programming. In December 1923 the National Carbon Company launched what became the Eveready Hour to promote its radio batteries, integrating music, drama, and talk into a single programme. Eveready set a precedent for other major radio equipment manufacturers in sponsoring regularly scheduled programmes. ${ }^{\text {vii }}$ In October 1925 the leading set manufacturer Atwater Kent launched the 'Atwater Kent Hour', which rapidly became the most popular U.S. radio programme, featuring top musicians and costing the firm \$7,000 per week by the 1926-27 season. ${ }^{\text {ix }}$ In April 1928 RCA launched the 'RCA Demonstration Hour', breaking the tradition of prime programming being restricted to the evenings. Broadcast each Saturday at 2.30 EST, it enabled retailers to demonstrate a quality music programme. ${ }^{\mathrm{x}} \mathrm{RCA}$ also played a leading role in the development 
of national networked broadcasting, culminating in the launch of its National Broadcasting Company (NBC) network in the fall of 1926.

Radio ownership greatly outpaced the diffusion of other appliances such as vacuum cleaners, refrigerators, and washing machines, reflecting radio's role as a 'counter-status luxury', with utility varying inversely with income (as higher income groups have more substitutes for its entertainment services). ${ }^{\mathrm{xi}}$ Rapid diffusion occurred despite radios being initially very expensive and often requiring costly external antennae, plus frequent servicing. Demand was initially dominated by classic 'early adopters' - radio enthusiasts and homeconstructors, who were more interested in the technical challenges of radio than in what was being broadcast. Homemade sets out-numbered factory-made receiver sales until 1925, while early listeners' first priority was often distance of reception. ${ }^{\text {xii }}$

However, by the mid-1920s mainstream users, who were chiefly interested in programme content, began to dominate the market. The advent of national programming also contributed to a decline in the importance listeners placed on distance, relative to characteristics such as tone, selectivity between stations, simplicity of operation, and

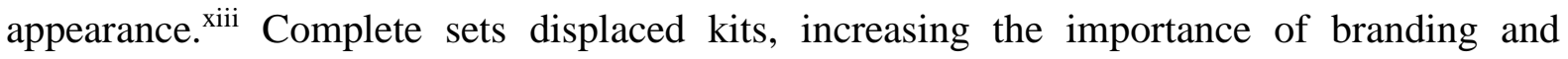
effective distribution systems. These required efficient sales organizations to promote this new product locally, provide after-sales service, and arrange instalment credit for what was initially a very high-ticket durable.

Value chains are useful devices for analysing the coordinating mechanisms governing the design, production, and marketing of consumer durables. They identify both the key players involved in organizing the sequence of activities that brings the good to the consumer in a particular format, quality, and price and the ways in which their actions impact on the nature of competition and the distribution of profits at each stage of the production and distribution process. The value chain literature identifies two typical governance forms producer-driven chains - coordinated by key manufacturers (typically those commanding strategic technologies), and buyer-driven chains - coordinated by firms responsible for final distribution. Buyer-driven chains tend to be more common in labour-intensive industries, while consumer durables involving new technologies are generally dominated by producerdriven chains. ${ }^{\text {xiv }}$

In producer-driven chains key manufacturers typically take responsibility for coordinating both suppliers and distributors. ${ }^{\mathrm{x}}$ This enables them to dominate marketing and to 
capture a disproportionate share of profits via their control over branding and design. However, each stage of the value chain is likely to benefit from participation (compared to un-coordinated market competition), as by coordinating marketing and distribution the lead firm can both add value to these stages and impose some barrier against new entrants.

Much research on producer-driven value chains for new consumer durables during this period has focused on the automobile sector, where, as Richard Tedlow noted, manufacturer-dealer relations were 'marked by often bitter conflict.' ${ }^{\text {xvi }}$ Leading auto producers used their considerable market power over dealers to impose franchise contracts, which could be cancelled with little if any notice and without which continued activity in the sector was often not possible. This in turn assisted them in pressuring dealers into both accepting close monitoring and coordination of their activities and in taking on various costs, which they would otherwise have borne directly. ${ }^{x v i i}$ Examples include shipping unwanted stock (in excess to dealers' requirements, sent at the end of the production year for that model, or packed with accessories) and pressure to use manufacturers' retail finance facilities. $^{\text {xviii }}$

While autos was a highly oligopolistic sector dominated by three players, radio developed much greater competition in all price ranges. Radio Corporation of America (RCA), initially looked set to dominate, obtaining what was believed to be a radio patent monopoly, under a U.S. Navy-sponsored initiative to unify American radio patents in a single domestically-owned concern. RCA initially marketed radios produced by the two main firms that pooled their patents for its formation - General Electric and Westinghouse. Yet a failure to successfully coordinate production, together with some loopholes in the exclusivity of key patents it controlled, resulted in RCA gaining less than a quarter of the receiver market during 1922-27. Meanwhile anti-trust threats and political pressure increasingly tempered the power of its patents as an entry barrier. ${ }^{\text {ix }}$ However, its technical leadership and strong position in the tube and components markets enabled RCA to retain its status as the largest radio equipment producer and leading set manufacturer by value.

Radio manufacture became a relatively fragmented industry compared to autos (or high ticket labour-saving durables such as refrigerators, vacuum cleaners, and sewing machines); as late as 1940 the largest receiver manufacturer accounted for only 14.4 per cent of sales and the largest three controlled just 37.4 per cent of the market. ${ }^{\mathrm{xx}}$ Vigorous competition between dozens of significant manufacturers, together with rapid technical 
obsolescence in this dynamic sector, gave rise to a near-universal strategy of annual model changes. ${ }^{x i}$ Moreover, demand for new models proved highly unpredictable, owing to the speed of innovation and the intensity of competition. ${ }^{x x i i}$ These conditions had important implications for distribution networks, on account of both the weaker market power of individual manufacturers and the impracticality of manufacturers looking to dealers to hold their inventory over the slack season. ${ }^{\text {xiii }}$

Demand for radios, like that for cars, was highly seasonal. ${ }^{\text {xxiv }}$ In autos General Motors (GM) successfully pioneered a strategy of building up massive inventories in their winter slack season, underpinned by a distribution strategy whereby their dealers carried the stocks. Franchised dealers were required to hold GM inventory on their premises, the retailer's costs in turn being covered by (often manufacturer-owned or associated) finance companies, who carried their inventory loans and purchased their retail instalment sales contracts. ${ }^{\mathrm{xxv}}$ However, given the unpredictability of demand for radios, this strategy proved impractical. Meanwhile radio's fragmented industrial structure prevented control via GM's system of franchise contracts subject to termination without notice, as dealers could turn to other brands.

Manufacturers responded to the high uncertainty of demand for new models and strong demand seasonality by using labour-intensive production systems, which were flexible with regard to the scale of production, but did not offer substantial scale economies. Meanwhile economies of scope were obviated by many components being externally sourced from specialist firms. ${ }^{\text {xxvi }}$

\section{Co-ordinating distribution}

Major radio manufacturers typically organized distribution via independent wholesalers, who were given exclusive territories and in turn served independent dealers. However, through co-operative and co-ordinated advertising; dealer educational activities; and a variety of other assistance with marketing and credit provision, manufacturers sought to develop strong relationships with retailers. In return, dealers were expected to follow their marketing policy and prioritise their brand over the others they stocked for activities such as door-to-door canvassing, window displays, or customer recommendation. This addressed a classic problem regarding distribution via independent dealers - if the dealer bore all the 
costs of their own promotional activities they would engage in less promotion expenditure than the manufacturer (who shared in the benefits) found optimal. ${ }^{\text {xxvii }}$

David Sarnoff of RCA devoted considerable time during 1922 and 1923 to telling jobbers and retailers in the electrical goods and musical instrument trades how radio was to be marketed - addressing their conventions or writing in their journals. His proposed distribution model proved remarkably prescient, foreshadowing most major developments during the 1920s. Sarnoff emphasised that the enthusiast home-constructor era was temporary and that radio would soon be sold as an entertainment durable and a piece of furniture: 'a device which has a very important bearing on our home life, for its sphere is one of culture, education and entertainment... somewhat of the characteristics of the phonograph and other musical instruments... not a mere electrical utility...' To achieve this, retailers should provide:

an attractive store to fit in harmoniously with the accustomed methods of selling musical instruments... the adoption of intensive selling practices, such as special demonstrations, demonstrations in the home, a reasonable amount of local advertising, and inauguration of all those special methods, which have been found valuable in other business in carrying on intensive selling campaigns. ${ }^{x x v i i i}$

Sarnoff urged dealers to make their stores attractive to women (whom, he said, accounted for 80 per cent of phonograph sales) and employ staff who could sell on the basis of appearance, simplicity of operation, and value for money. This might involve window displays showing the radio taking pride of place in the living room; separate salesmen to deal with radio hams and mainstream customers; and crews of 'outside' salesmen, who would arrange home trials through door-to-door canvassing, to break down sales resistance and inertia (including fears that radios would be too complicated to operate). ${ }^{x x i x} \mathrm{He}$ also emphasised the need for time payment schemes to increase affordability. ${ }^{\mathrm{xx}}$

By the mid-1920s retailers were beginning to note this transition towards a new type of customer and, as Sarnoff had predicted, the need for retail practices that met (increasingly) her needs. Dealers characterised women as being more demanding customers than men expecting a radio set to be reliable, easy to operate, and attractive in appearance. They were also said to purchase only after undertaking comparison shopping; 'for a woman largely sells the merchandise she buys to herself'. ${ }^{x x i}$ One dealer proposed employing some female indoor sales staff - building on the precedent of music retailing. ${ }^{\text {xxii }}$ Yet subsequent trade press 
discussions generally assumed the national sales force to be uniformly male, a result corroborated by a 1930 U.S. Department of Commerce radio dealer survey. ${ }^{\text {xxxii }}$ The absence (or invisibility) of women sales staff may reflect popular assumptions that technical competence in radio was a masculine characteristic, or the need for salesmen, on occasion, to deliver bulky console sets to households. However, during the 1920s men dominated most areas of direct sales (especially door-to-door), including sectors such as brushes, where women were the principal customers. ${ }^{\text {xxxiv }}$

Most major manufacturers, including RCA, Crosley, Zenith, and Atwater Kent, adopted a distribution policy based on assigning territories to appointed wholesale distributors, who in turn supplied only authorised dealers (who nevertheless typically also sold other radio brands). ${ }^{\mathrm{xxv}}$ Some, including RCA, assigned sales quotas to each wholesaler. ${ }^{\text {xxvi }}$ A minority operated their own wholesale branches, while large retail customers such as mail-order houses, chain stores, and department stores, often placed their orders directly with the manufacturer. ${ }^{\text {xxxvii }}$ By limiting local competition, authorised dealerships constituted a 'carrot' to encourage dealers' conformance with the manufacturer's retail model. For example RCA, which moved to authorised dealerships in 1926, had the following requirements: a well-located store, with a well-appointed showroom, including sound booths; the use of window displays to promote their product; an 'energetic' sales organization; adequate servicing facilities; and 'An advertising policy which is as liberal as the dealer's circumstances will permit'. xxxviii

Authorised distributors were rewarded with discounts from list prices that grew significantly over the 1920s. In August 1922 RCA offered dealers 25\% discounts for orders up to $\$ 499$ and $33.3 \%$ for larger orders, while their wholesales received a $46 \%$ discount (broadly in line with a December 1922 estimate for the sector as a whole). ${ }^{\text {xxix }}$ Discounts subsequently rose - by February 1928 RCA dealers and wholesalers received discounts of 40 and $52.5 \%$ respectively. ${ }^{\mathrm{xl}}$ They still had to be persuaded to hold significant stocks, given that market conditions often led to reductions in list prices, which devalued their inventory. RCA addressed this via a price protection policy. In the event of list price reductions, distributors and dealers were refunded the difference between the old and new price on each unsold set. ${ }^{\text {xli }}$ Zenith achieved the same goal via a policy of no price reductions (underpinned by a conservative production strategy, relative to distributors' orders) to avoid dealers having to worry about suddenly finding their sets, 'worth fifty cents to the dollar.' ${ }^{\text {xlii }}$ 
Maintaining capacity production was problematic in industries subject to strong seasonality and annual model changes - factors which had led GM to experiment with demand forecasting and, from the middle of 1924, to require statistical reports from dealers at 10-day intervals. ${ }^{\text {xliii }}$ Zenith's spectacular success from the mid-1920s was attributed to their introduction of a production and inventory planning system, based on distributors' purchase commitments - updated quarterly. By facilitating price stability, the system was also said to have built loyalty among distributors and dealers. ${ }^{\text {xliv }}$

RCA Victor (the radio division formed after the merger with Victor Talking Machine Co.) introduced a production control plan from the fall of 1930. Distributors were required to secure sales reports from each of their dealers and collate them into weekly reports for RCA. $^{\text {xlv }}$ By summer 1931 distributors were also required to provide estimates of their requirements, to reduce the interval between RCA's materials purchase and use to 60 days (compared with 120-180 days in 1929). ${ }^{x l v i}$ However, problems of coordinating production and sales persisted throughout the 1930s. ${ }^{\text {xlvii }}$ In addition to production, or market volatility, problems, an RCA review identified cases where they had over-sold dealers on likely sales, or where some smaller distributors had responded to RCA's 'pressure selling' by accepting larger stocks than they could move. ${ }^{\text {xlviii }}$

An extensive volume of information also flowed downstream from manufacturers to distributors and dealers, via bulletins, national and regional sales conventions, and in-house journals. For example Crosley was producing the Crosley Radio Weekly by January 1924, later replaced by the Crosley Broadcaster. In addition to informing distributors and dealers about their general activities, these included information on marketing assistance; letters from dealers (generally supporting the company's marketing policy); and articles extolling the merits of activities such as direct selling. ${ }^{\text {xlix }}$

Supporting dealers was seen as essential to developing strong relationships that would foster loyalty to their brand and retail policy. This was achieved through extensive expenditures on co-operative and co-ordinated advertising and 'sales' helps' (point of sale advertising material) a strategy also intensively exploited by refrigerator manufacturers. ${ }^{1}$ Cooperative advertising appears to have become popular towards the end of the 1920s, as shown by advertising spend data for RCA, in Table 1. This included a plan under which RCA paid half the costs of dealers' direct mailings featuring their products. ${ }^{\text {li }}$ Crosley had initiated support for direct mailing by the start of the 1928/29 season, dealers being offered a 
set of three mailings for each potential customer, delivered to the dealer stamped and addressed for $15 \mathrm{c}$, for use in conjunction with a door-to-door sales campaign. ${ }^{\text {lii }}$

\section{[Table 1 near here]}

RCA's co-operative advertising appears to have grown considerably over the depression. By the fall of 1931 RCA Victor operated a system whereby they and the local distributor each paid 25 per cent of a dealer's print advertising costs, providing certain conditions were met (including at least 50 per cent of total advertising space being used to illustrate RCA merchandise and the RCA Victor name featuring at least as large as that of the store). ${ }^{\text {liii }}$ For major accounts, such as chain stores, RCA offered to meet 50 per cent of advertising costs, for expenditures up to $5 \%$ of the chain's purchases. ${ }^{\text {liv }}$

Manufacturers also engaged in extensive advertising support activities for dealers, including 'ready-made' newspaper ads on which stores could add their own details. Other aids included billboard posters; window display material; store interior displays; electric signs, and advertising novelties. ${ }^{\text {lv }}$ Some also provided sales training. By 1925 De Forest's sales department was running a radio salesmanship and service correspondence course, which around 800 dealers had completed, involving a combination of home study and discussion meetings among relevant staff in each store. ${ }^{\text {lvi }}$

Manufacturers also sought to coordinate their own customer advertising with their dealers. As Table 1 shows, direct space advertising over 1923-29 was equivalent to around 5.3 per cent of RCA's sales revenue and accounted for two thirds of its advertising expenditure. By 1927 RCA was supplementing its national magazine advertising with newspaper advertising in major cities, while urging its distributors to encourage dealers to arrange tie-in promotions, such as set demonstrations..$^{\text {vii }}$

\section{The radio dealer}

In 1926, when the launch of NBC inaugurated national network broadcasting, an estimated 31,000 radio retailers and 1,000 wholesalers sold the output of some 2,000 manufacturers to a national radio audience of around 20,000,000, owning 5,000,000 receivers. ${ }^{\text {lviii }}$ Yet despite the rapid growth of equipment sales, the retail sector demonstrated significant dealer mortality. The National Electrical Manufacturers Association sponsored a 
Department of Commerce survey of dealers (defined as any retailer who carried an average stock of $\$ 500$ or more in radio merchandise), covering the three quarters from October $1^{\text {st }}$ 1927. Of over 31,000 dealers identified in each quarter, more than 1,000 had gone out of business by the next quarter - suggesting an annual failure rate of about 13 per cent. ${ }^{\text {lix }}$ Dealers were required to carry significant stocks of expensive, rapidly depreciating, equipment. A 1930 national survey found that retailers typically stocked around five different brands of radio and that stocking an excessive range contributed to failures, by accentuating obsolescence risks. ${ }^{1 x}$ Given that in 1933 the largest nine radio set manufacturers were said to account for 74 per cent of industry turnover, a typical store would thus stock around half the leading brands. . $^{\text {i }}$

Problems of depreciating stocks were accentuated by strong demand seasonality. The 1930 survey found that 39 per cent of business was conducted over the October-December quarter, compared to only 16 and 17 per cent respectively for the April-June and JulySeptember quarters. A number of dealers turned to supplementary lines, principally electrical appliances, to reduce seasonal fluctuations. ${ }^{\text {1xi }}$ Dealers also faced problems with trade-ins, estimated to feature in at least 40 per cent of radio sales by the late 1920s. These both lowered margins and gave the retailer the dilemma of either selling used radios in competition with new stock or disposing of them either at a total loss, or at a price making

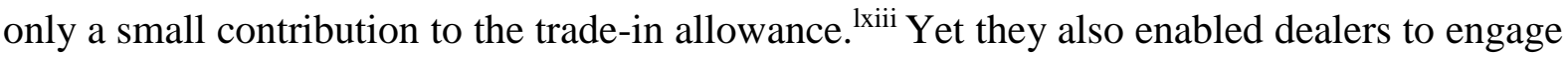
in price competition, without opening flouting manufacturers' list prices.

Business risks were further accentuated by credit sales. Radios were relatively expensive household durables in the 1920s. As Table 2 shows, the average 1924 unit price of a home radio was around $\$ 67.00$, plus the cost of four or five tubes (sold separately, at around three dollars each), batteries, and other accessories. ${ }^{\text {lxiv }}$ As radios became grander and more complex, prices rose further, peaking at \$133 in 1929 (again, net of tubes). Not surprisingly, credit facilities rapidly became integral to retail success.

In 1928 RCA reported estimates that approximately 70 per cent of radios were sold on deferred payments; while an estimate for 1930 put the figure at 75 per cent; on a par with other high-ticket consumer durables. ${ }^{\mathrm{lxv}}$ Of 33 dealers surveyed by the Department of Commerce in 1930, only one conducted business on a cash-only basis, while the rest made an average of 80 per cent of radio sales on credit. Most financed deferred payments using their own funds or bank loans; only 21 per cent relied exclusively on a finance company. The most 
common terms involved a 10 per cent down-payment with the balance payable monthly over 10-12 months, typically at 6 per cent annual interest. .xvi $^{\text {. }}$

\section{[Table 2 near here]}

Several manufacturers arranged credit plans for their dealers. By September 1928 RCA was advertising a plan run by Commercial Investment Trust, which provided dealers with an immediate advance of 90 per cent of the un-matured face value of their paper, less a discount charge. The remaining 10 per cent was then deducted from the final payment on the contract. Under this scheme the only cost to the dealer was the service charge, which could be passed on to the purchaser by adding 0.5 per cent per month to the cash price. ${ }^{\text {xvii }}$ Unlike in autos, where dealers claimed to be coerced into using finance companies tied to manufacturers, even facilities promoted by the set-makers typically involved independent finance companies. ${ }^{\text {lxviii }}$ This reflected the weaker market power of individual manufacturers in radio and the impracticality of dealers holding large inventories, given highly unpredictable obsolescence. However, the absence of manufacturer-tied credit removed a potential source of cyclical demand stabilisation. One justification for tied finance in autos was that it would be maintained during hard times, when independent finance companies might tighten provision. ${ }^{\text {lxix }}$ Indeed, during the depression the availability of radio commercial time-payment paper tapered off, becoming practically non-existent by 1932 according to Radio Retailing. Dealers were thus forced to finance credit directly, which gave bettercapitalised firms a competitive edge. It was not until the mid-1930s that finance companies again began to show interest in this sector. ${ }^{1 \mathrm{xx}}$

\section{Taking radio to the prospect's home}

Canvassing was already a proven sales method for phonographs and was quickly adopted by the radio trade. ${ }^{\text {lxxi }}$ By the mid-1920s it had become common for dealers to engage in door-to-door selling, typically offering to set up a radio in the home and leave it for several days on trial. This was a relatively novel innovation, though it had been employed by Eureka Vacuum Cleaner Co. from 1912 and was widely used by refrigerator manufacturers during the 1920s. ${ }^{\text {lxxii }}$ Home demonstrations had a number of important attractions for radio allaying fears that operation might prove too complex, or that reception would be too weak, and introducing the family to broadcast entertainment over several days. ${ }^{\text {1xxiii }}$ Buyers often perceived home demonstrations as a good way of testing a set's performance, though from the dealer's perspective it was seen primarily, 'as a lever to accelerate the normal process of 
the realization of the need... - to stimulate desire. ${ }^{\text {'lxiv }}$ It also avoided price comparison with cheaper models, boosting the sale of large console sets.

\section{[Figure 1 near here]}

A 1925 Radio Merchandising survey found that 38 per cent of radio dealers in the USA and Canada used door-to-door canvassing. ${ }^{\text {lxxv }}$ J.J. Moore, the Radio Dept. manager of New Orleans department store Maison Blanche, stated in 1925 that the most important factor in radio sales was home demonstration, followed by price and service. ${ }^{\text {lxxvi }}$ In 1929 Radio Retailing estimated that most radio dealers employed at least two outside salesmen full-time, with more recruited for special campaigns. Paying a straight commission of 15 per cent or less (with salesmen covering their own expenses) was considered most satisfactory. ${ }^{\text {lxxvii }}$

Radio manufacturers vigorously promoted door-to-door selling. For example, in February 1929 Crosley Broadcaster informed dealers that, 'During 1928 the sale of Crosley sets was built up to record-breaking proportions by means of home demonstration.' ${ }^{\text {lxxviii }}$ Yet radio trade journals were receiving a growing correspondence from dealers arguing that direct sales were of limited, if any, attraction for them. Retailers found direct selling difficult to manage, expensive, and - given the rapidly growing proportion of replacement sales - a high cost means of fighting for people already in the market, rather than creating a new market. Moreover, the minimum efficient scale for direct selling- a team of four or five salesmen working collectively from a single vehicle -required a much larger territory for year-round employment than the catchment areas of most stores. The main exceptions were large traders such as department stores, though these were said to follow conservative selling policies, often eschewing outdoor canvassing. ${ }^{\text {lxxix }}$ Personnel problems represented another key obstacle; a 1930 survey noted that, 'many store managers have found it impossible to secure men who are intelligent and sufficiently aggressive... More than two-thirds... definitely stated that the problem of securing the right type of men... was continually bothering them. ${ }^{1 x x x}$

By the late 1920s Victor's Talking Machine Division was seeking to address these problems by establishing direct sales organizations in each wholesaler, put at the disposal of successive dealers for short periods of intensive selling. Where circumstances warranted, the wholesaler might turn over one or two experienced salesmen to the dealer on a permanent basis. It was anticipated that this would boost sales both directly and by encouraging retailers to intensify their own direct sales efforts. ${ }^{\text {lxxxi }}$ The 'Victor Resale Plan' followed the broad outlines of established resale plans in other industries, such as vacuum cleaners, with the 
manufacturer running the direct sales effort and the dealer being responsible for itinerary, instalment credit, and paying a 10 per cent commission on sales (which, together with a further 2.5 per cent commission from the wholesaler, would fully finance the programme). Based on experience in the South, crews of five salesmen were expected to close 30 sales per week (10 radiograms and 20 radios). They would be remunerated via a drawing account of $\$ 30$ per week against 5 per cent commission and all expenses. ${ }^{1 x x x i i}$ Atwater Kent was recommending a broadly similar plan by 1929, based on deploying seven salesmen for intensive campaigns of three or four weeks, followed by the permanent retention of two or three. ${ }^{\text {lxxiii }}$ However, manufacturer-organized direct selling does not appear to have become firmly established before the depression curtailed such activity.

A 1928 Radio Retailing national survey of 109 dealers found that around 40 per cent of sales were made through canvassing, with those groups of firms undertaking the highest, and lowest, sales being most reliant on canvassers. The survey was pessimistic regarding the value of direct sales: 'outside selling is more costly to the merchant and... its percentage cost is not reduced through increased volume to a figure comparable with the cost of inside selling. '1xxxiv Scepticism intensified during the depression. As an Albany dealer noted, 'Too often... this makes money for everybody concerned except the dealer.' ${ }^{\text {lxxxv }}$ Margins were said to be squeezed by opportunistic 'joy riders', who obtained a series of sets from various dealers on home demonstration with no intention of purchasing. One Atlanta dealer was reported to have found that each unsuccessful demonstration cost $\$ 15$ (when factors such as damage to cabinets and tube replacements were included), while only one in three resulted in a sale. The resulting costs (including at least $\$ 5$ for each successful sale) wiped out almost all dealer profit. lxxxvi A March 1930 Radio Retailing survey of 1,000 dealers broadly corroborated these figures. Each successful, and unsuccessful, home demonstration was found to cost $\$ 4.51$ and $\$ 13.43$ respectively. ${ }^{\text {lxxxvii }}$

A Radio Retailing survey of 109 radio retailers allows us to test whether dealers' perceptions regarding the poor cost-effectiveness of intensive canvassing were justified. ${ }^{\text {lxxxviii }}$ The sample was said to be well balanced geographically and to cover all types of outlet dealing in radio. ${ }^{\text {lxxix }}$ The survey year, 1928, was described as the most profitable to date, with average net profits having increased by 3.3 per cent of sales compared to their previous (1926) survey. Yet, the survey was surprisingly pessimistic, noting that rising net margins were driven by higher gross margins (boosted by lower stock obsolescence during a year of vigorous demand), while costs had actually increased between the two surveys, by 0.8 per 
cent of net sales. The report singled out rising selling costs as the chief problem. These had risen from 9.4 to 12.0 per cent of net sales, while publicity expenses had actually fallen, from 5.1 to 3.3 per cent (partly owing to rising manufacturers' co-operative advertising). Rising selling costs were, in turn, attributed to increased door-to-door canvassing. ${ }^{\mathrm{xc}}$

The survey included information on net retail sales; costs of merchandise sold; gross profits (sales minus cost of merchandise sold); and expenses - divided into occupancy, selling, publicity, administration, servicing, and other costs. ${ }^{\text {xci }}$ To test whether radio manufacturers pushed their retailers into unattractively high levels of selling expenditure (from the retailer's perspective), we compare the relative impact of publicity and selling expense on retailers' gross and net profits. Our results, for a cross-section of 100 retailers, are shown in Table 3. ${ }^{x i i}$ The estimates are derived using Generalised Least Squares and are transformed in log-form to enable the coefficients to be interpreted as marginal effects. Given a view among some dealers that door-to-door sales reduced the need for a well-located store, we also include occupancy expenses as a control variable in both estimations.

The table shows that the return on gross profit for selling expenditure was about 40 per cent higher than that for publicity spend. Conversely, the return on net profit (after deducting expenses) on publicity expenditure was more than two and half times as high as that for selling - assuming that the coefficient of selling, which is insignificantly different from zero, is consistently estimated. In both cases the results are well determined, being significant at the $1 \%$ level. Occupancy expenditure similarly shows a markedly greater return on net profits than that for selling expense, despite having a lower return on gross profits. The analysis thus indicates that direct selling was particularly successful in boosting gross profits, thus benefiting the manufacturer and wholesaler, but offered lower returns than advertising or better retail premises, once the retailer's costs are deducted.

\section{[Insert Table 3 here]}

However, while door to door selling may not have advantaged the retailer - compared to a situation where all local dealers abstained from canvassing - it does appear to have acted as a significant barrier to entry. Canvassing was a specialist activity, with significant minimum costs for dedicated staff and vehicles, which were most efficiently employed in teams operating on a full-time (though perhaps temporary) basis. By reducing the pool of customers who purchased radios via conventional shopping, direct sales thus restricted the 
potential customer base for vendors not prepared to take on these costs. Moreover, authorised dealers for major radio brands had a competitive advantage in canvassing, as heavy manufacturer advertising boosted brand recognition and was often coordinated with dealers' direct sales campaigns - increasing the likelihood that the salesman would receive a positive reception. Thus, by deterring market entry, canvassing may have been of greater benefit to the specialist radio retailer than was evident from its contribution to net margin.

\section{The depression, the 'midget', and the transformation of radio value chains}

The depression and its aftermath witnessed a dramatic decline for the specialist radio retailer. Despite a rise in U.S. radio output from 4.44 million sets in 1929 to 6.03 million in 1935, employment in the 'household appliances, radio dealers' Census classification had fallen by 34.8 per cent, to 71,971 . Dollar sales by stores in this group had declined by 53.4 per cent (compared with 32.2 per cent for all store sales), while the number of dealers had fallen by 26.3 per cent. ${ }^{\text {xciv }}$ This was the product of technological changes that transformed radio from an expensive, bulky, product, requiring frequent servicing, to a cheaper portable appliance.

A new compact radio format, known popularly and in the trade as the 'Midget', first appeared in California in 1929 and - as is often the case for new products that challenge incumbent formats - was initially produced by small start-ups that took advantage of the availability of cheap, externally-sourced, components. ${ }^{\text {xcv }}$ Midget sets were essentially "market breakthroughs" - providing substantially higher customer value (for a segment of the market) using the industry's established core technology, rather than "radical innovations" based on a substantially different technology. ${ }^{\text {xcvi }}$ The first midgets were stripped-down versions of standard radios, in smaller cabinets. Miniaturised components were only introduced from 1932, by Emerson, though these were functionally identical to conventional parts (in contrast to later episodes of miniaturisation, such as the transistor, or microchip).

During the 1920s large manufacturers had generally avoided price competition, relying on strong brands, based on quality, innovation, and promotion. The midget's appeal was based on price, while performance initially did not meet accepted industry standards. However, as radio now provided all-day entertainment, with an increasing element of afternoon soap operas, sports, and other 'talk' content, purity of sound reproduction was becoming less important, especially for supplementary sets. Over the 1930s midgets 
experienced dramatic improvements in quality - challenging conventional radios for a progressively larger segment of the market.

These developments have strong parallels with the mobile phone industry, where economic recession at the beginning of this century depressed sales and triggered a shift in demand to low-price handsets. Marketing strategy thus shifted from quality and branding to aggressive pricing of entry-level phones, a sub-market where firms outside the established industry proved more successful than the market leaders. ${ }^{x c v i i}$ Those firms that became market leaders in small radios had been active in the industry prior to 1929, but not as major receiver manufacturers. Crucially, they typically had established distribution systems. For example, Philco (which tied for receiver market leadership, by volume, with RCA by the end of the 1930s) was a long-established electrical goods producer, which had become a market leader in radio battery eliminators, but only entered receiver production in 1928 (capitalising on its formidable distribution network). Similarly Emerson, which became the largest specialist producer of small radios, had been selling radios since 1924, but as a dealer in surplus equipment rather than a manufacturer. ${ }^{\text {xcviii }}$ Major retailers such Montgomery Ward and Sears Roebuck also took advantage of the shift from brand- to price-based competition, contracting-out the manufacture of sets sold under their own retail brands. ${ }^{\text {xcix }}$

Despite lower prices, and profit margins, retailers welcomed the midget as something distinctive and novel in a depression market burdened by distress sales. ${ }^{c}$ Midgets offered the potential to draw in customers who either could not afford a conventional set, had small apartments, or wanted an additional receiver. ${ }^{\text {ci }}$ Their contribution to total volume sales rapidly increased, reaching 60 per cent of all radios sold between $1^{\text {st }}$ December 1932 and $1^{\text {st }}$ May 1933. ${ }^{\text {cii }}$ During the 1930s their weight and cost declined sharply (eventually retailing from under \$10.00), while performance improved. An innovation initially widely viewed as a 'depression product' dominated unit sales by the end of the decade. ${ }^{\text {ciii }}$ Midgets also took the lead in styling, appearing in distinctive modern cabinets, often using coloured Bakelite. Meanwhile the radio market was experiencing a general trend towards lower unit prices, as shown in Table 2.

Midget radios undermined the quality-branding competitive advantages of the industry's established leaders. Of the four leading set makers in 1929, three - Atwater Kent, Grigsby-Grunow, and Crosley - proved unable to weather this storm. ${ }^{\text {civ }}$ Only RCA remained as a major player in radio manufacture, though this was largely due to its strengths in patents, 
components production and, increasingly, broadcasting. Moreover, its market position had been strongest in the highest price classes of sets and it successfully held its lead in these segments during the 1930s.

As a 1930 article noted, the midget appeared to have answered the radio retailer's dream, 'no deliveries, no financing, no collection grief, no service. "Just one long, sweet process of fittin' em with tubes and passin' em over the counter to eager buyers." ${ }^{\mathrm{cr}}$ Yet by reducing the need for home demonstration, delivery and servicing; credit; and showrooms worthy of a prestige piece of furniture; the midget eroded the key differentiating advantages of the specialist dealer. Moreover, as models had shelf lives of several years, rather than the annual model changes characteristic of conventional radios, the specialist retailer's skills of managing rapidly depreciating inventory commanded less of a premium. By removing the need for the most troublesome aspects of the dealer's activities, the midget had opened up radio to the general retailer, who sold on price and did not require close co-operation with the manufacturer.

Thus it was the weakness, rather than strength, of manufacturers' control over dealers, that undermined their long-term survival. Established manufacturers proved powerless to block midget radios, in contrast to British set-makers, who supressed the format throughout the 1930s (via a black-list of non-conforming retailers - which was perfectly legal in the absence of any effective British anti-trust legislation). ${ }^{\text {cvi }}$ In a depression market, specialist dealers had embraced what they believed to be a novelty and loss-leader, apparently unaware of the fundamental threat it posed to their business model.

\section{Conclusion}

Like the refrigerator and washing machine, the radio of the early 1920s was an expensive mechanical novelty, requiring intensive advertising, considerable after-sales service, and costly door-to-door canvassing. By the late 1930s all three of these products had been largely transformed into 'staple' merchandise, increasingly marketed using standard retail channels and methods. However, while refrigerators and washing machines experienced this transition as an evolutionary process, with new innovations tending to reinforce the first mover advantages of the leading firms and their established distribution networks, in radio it 
was marked by major disruptions to established industry structures and distribution channels. ${ }^{\text {cvii }}$

Interwar radio had more in common with modern high-tech durables such as mobile phones. Development was characterised by rapid technological change, punctured by frequent 'technological discontinuities' - that made earlier vintages of radios obsolete (for at least some market segments). Such patterns do not conform to classic Product Life Cycle models - where markets typically become increasingly dominated by early entrants, drawing on first mover advantages. ${ }^{\text {cviii }}$ Michael Tushman and Philip Anderson distinguish between 'competence-enhancing' technological discontinuities (building on existing know-how within a product class) and 'competence-destroying' technological discontinuities - new product sub-classes that require different skills and competitive strengths. The latter are typically launched by firms outside the established industry, leading to rapid changes in industry structure and posing severe problems for established leaders. ${ }^{\text {cix }}$

During the 1920s discontinuities in radio technology were generally of the competence-enhancing type, involving new circuits or features that could be most rapidly exploited by existing market leaders. ${ }^{\mathrm{cx}}$ Conversely, the midget format constituted a competence-destroying discontinuity, competing on price, rather than quality. This posed a dilemma for market leaders with competencies based on quality, promotion, and branding. As predicted in the literature on technological discontinuities, this triggered both rapid firm entry and exit, with most leading manufacturers facing a rapid decline in market share, or liquidation. ${ }^{\text {cxi }}$

In common with more recent market breakthroughs, these changes had important implications for established relationships between manufacturers and their retailers. ${ }^{\text {cxii }}$ Distribution networks based on co-operation failed to block the midget's introduction, owing to manufacturers' limited control over their dealers. Each typically stocked several brands of radio and faced no contractual restrictions on stocking this new format. Nor could informal pressure achieve this end, in an environment of sharply declining sales and prices. Yet by embracing the midget radio the specialist dealers popularised a format that required substantially less marketing, servicing, and instalment credit and thus undermined their barriers to entry. Radio thus represents an important precursor of the modern pattern of disruptive technological change in high-tech durables sectors, with even the strongest 
manufacturers and distributors having to be forever vigilant for the next innovation that might threaten their competitive advantage.

\section{Author biographies}

PETER SCOTT is Professor of International Business History at the Henley Business School, University of Reading, Great Britain, and Director of the Henley Business School's Centre for International Business History (CIBH). He has published extensively on consumer durables production and marketing, housing, household expenditure, and retailing. His monograph, The Making of the Modern British Home: The Suburban Semi and Family Life Between the Wars, was published by Oxford University Press in 2013.

PROFESSOR JAMES T. WALKER is Head of International Business and Strategy, Henley Business School, University of Reading, Great Britain. His research agenda is characterised by the application of empirical methods to solve real world problems and issues past and present. He has published in journals as diverse as Research Policy and Journal of Economic History, examining spatial competition in product markets and between firms, particularly in the retail and automobile industries; varieties of capitalism; academic performance and pay; and attitudes to multinational enterprises. 
Table 1: RCA's advertising expenditure as a percentage of sales, 1923-29

\begin{tabular}{|l|r|r|r|r|r|r|}
\hline Year & Space & Sales Promotion & Co-operative & Broadcast & Total (\%) & Total (\$) \\
\hline 1923 & 3.78 & 3.11 & 0.00 & 0.00 & 6.89 & 536,387 \\
\hline 1924 & 2.59 & 1.65 & 0.00 & 0.00 & 4.24 & $1,058,640$ \\
\hline 1925 & 5.30 & 2.59 & 0.00 & 0.00 & 7.89 & $1,595,772$ \\
\hline 1926 & 7.01 & 2.95 & 0.00 & 0.00 & 9.96 & $2,257,859$ \\
\hline 1927 & 5.40 & 1.78 & 0.17 & 0.30 & 7.65 & $1,783,365$ \\
\hline 1928 & 4.47 & 2.20 & 0.00 & 0.47 & 7.13 & $2,556,828$ \\
\hline 1929 & 9.57 & 3.10 & 1.02 & 0.66 & 14.35 & $3,294,191$ \\
\hline Total & 5.29 & 2.30 & 0.17 & 0.24 & 7.99 & $13,083,037$ \\
\hline
\end{tabular}

Source: Data sheet on RCA advertising expenditure, n.d., c. 1930, RCA, Victor Division, Records of the Office of the Company Historian Series II, 2069/2/2, Hagley Museum Archives.

Notes: Total sales figure for 1923 excludes tubes. Total sales for 1925 excludes $\$ 913,139$ of component parts supplied to Brunswick and Victor, as attribution between firms not known. 
Table 2: Sales of home radio apparatus in the United States (units and dollar values), 1922-34

\begin{tabular}{rrrrrrrr}
\hline & \multicolumn{2}{c}{ Radio sets* } & \multicolumn{3}{c}{ Radio tubes } & \multicolumn{2}{c}{ All equipment } \\
& $\begin{array}{c}\text { Units } \\
\text { (thousands) }\end{array}$ & $\begin{array}{c}\text { Value } \\
\text { (\$ million) }\end{array}$ & $\begin{array}{c}\text { Unit } \\
\text { Price }\end{array}$ & $\begin{array}{c}\text { Units } \\
\text { (thousands) }\end{array}$ & $\begin{array}{c}\text { Value } \\
\text { (\$ million) }\end{array}$ & $\begin{array}{c}\text { Unit } \\
\text { price }\end{array}$ & $\begin{array}{c}\text { Value } \\
\text { (\$ million) }\end{array}$ \\
\hline 1922 & 100.0 & 5 & 50 & 1.0 & 6.0 & 6 & 60.0 \\
1923 & 250.0 & 15 & 60 & 4.5 & 17.0 & 4 & 136.0 \\
1924 & $1,500.0$ & 100 & 67 & 12.0 & 36.0 & 3 & 358.0 \\
1925 & $2,000.0$ & 165 & 83 & 20.0 & 48.0 & 2 & 430.0 \\
1926 & $1,750.0$ & 200 & 114 & 30.0 & 58.0 & 2 & 506.0 \\
1927 & $1,350.0$ & 169 & 125 & 41.2 & 67.3 & 2 & 425.6 \\
1928 & $3,281.0$ & 388 & 118 & 50.2 & 110.3 & 2 & 690.6 \\
1929 & $4,438.0$ & 592 & 133 & 69.0 & 172.5 & 3 & 842.5 \\
1930 & $3,827.8$ & 332 & 87 & 52.0 & 119.6 & 2 & 501.0 \\
1931 & $3,420.0$ & 212 & 62 & 53.5 & 69.6 & 1 & 309.3 \\
1932 & $2,620.0$ & 125 & 48 & 44.3 & 48.7 & 1 & 196.0 \\
1933 & $3,806.0$ & 131 & 34 & 55.6 & 56.6 & 1 & 212.0 \\
1934 & $4,084.0$ & 151 & 37 & 55.2 & 56.6 & 1 & 235.0 \\
\hline
\end{tabular}

Source: Thomas Eoyang, "An Economic Study of the Radio Industry in the United States of America" (PhD thesis, Columbia University, 1936), pp. 73-85. Corrected using original data from, Radio Retailing (March 1933), 17-18; (March 1932), 18-19; (March 1931), 20-21.

Notes: Based on Radio Retailing data, shown at retail values. * Excludes cost of tubes. 
Table 3: Determinants of net and gross profits (GLS estimates: $n=100$ )

\begin{tabular}{|c|c|c|c|c|c|c|}
\hline \multirow[b]{3}{*}{ log Publicity } & \multicolumn{3}{|l|}{ Gross profit } & \multicolumn{3}{|c|}{ Net profit } \\
\hline & \multicolumn{2}{|l|}{ Coefficent } & \multirow{2}{*}{$\frac{\text { z-stat }}{(4.84)}$} & \multicolumn{2}{|c|}{ Coefficent } & \multirow{2}{*}{$\frac{\text { z-stat }}{(2.17)}$} \\
\hline & 0.247 & $* * *$ & & 0.348 & $* *$ & \\
\hline $\begin{array}{l}\text { log Selling } \\
\log \end{array}$ & 0.344 & $* * *$ & (5.13) & 0.135 & & $(0.74)$ \\
\hline Occupancy & 0.309 & $* * *$ & $(4.07)$ & 0.226 & & (1.10) \\
\hline Constant & 2.711 & $* * *$ & (7.72) & 2.809 & $* * *$ & (4.53) \\
\hline Loglikelihood & -32.55 & & & -125.17 & & \\
\hline
\end{tabular}

Source: S. J. Ryan, "109 Radio Merchants Answer the Question - What of Selling Costs," Radio Retailing (Sept. 1929), 52-4 \& 92.

Notes: $* * * \mathrm{p}<0.01 ; * * \mathrm{p}<0.05$. Coefficients are marginal effects. White corrected $\mathrm{z}$-statistics in parentheses. 
Figure 1: 'Realizing the need' via home canvassing and demonstration, as visualised by Radio Retailing in 1930

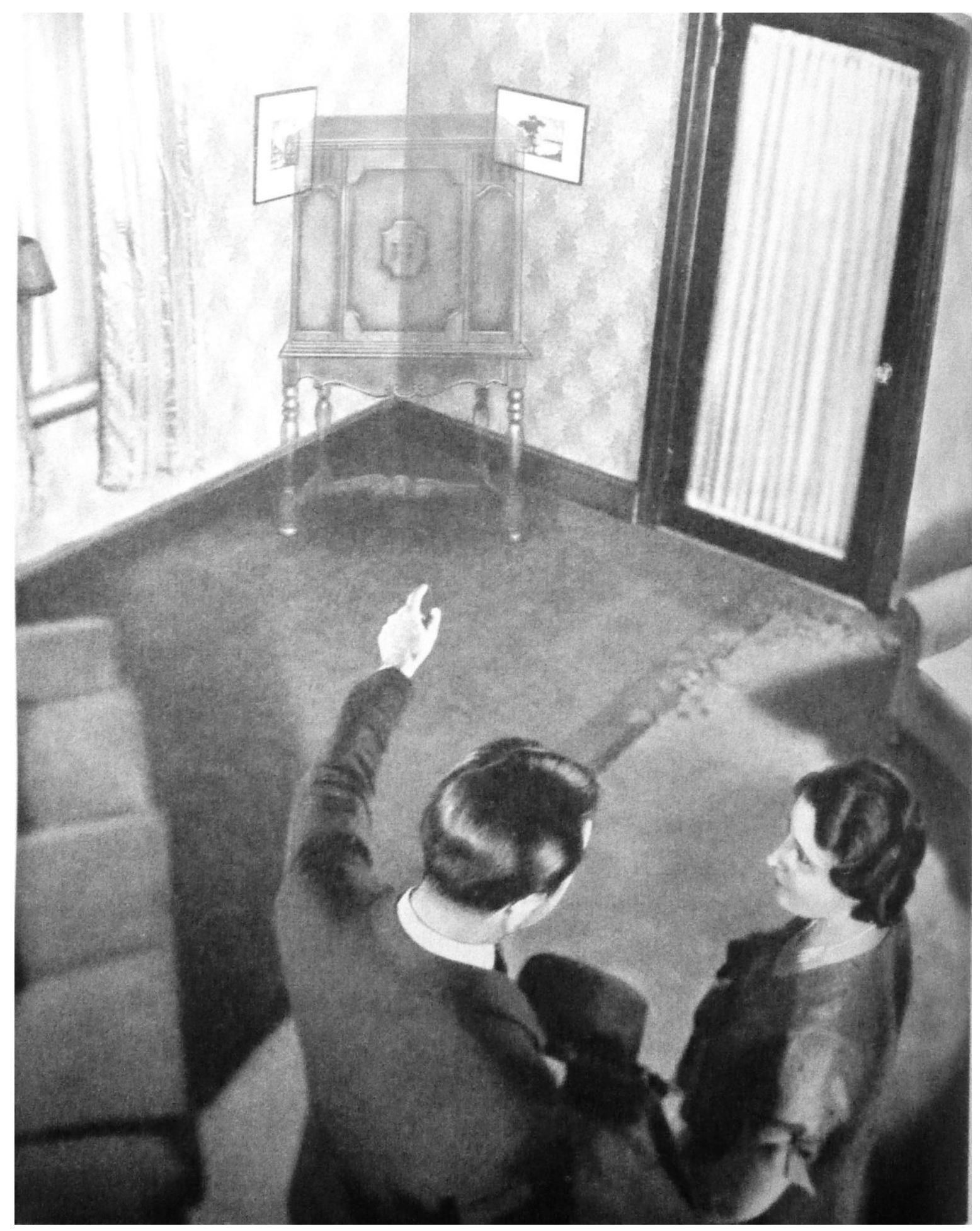

Source: H. U. Mann, "Selling in the home multiplies desire," Radio Retailing (May 1930), 22-24, p. 22. 
${ }^{\mathrm{i}}$ Michele Hilmes, Radio Voices. American Broadcasting, 1922-1952 (Minneapolis, 1997), 5-20; Stephen Fox, The Mirror Makers. A History of Advertising and its Creators (New York, 1984), 150.

ii Mary S. Mander, "The Public Debte about Broadcasting in the Twenties: an Interpretive History," Journal of Broadcasting 82 (1984): 167-185.

iii Andrew Godley, "Selling the Sewing Machine Around the World: Singer's International Marketing Strategies, 1850-1920," Enterprise \& Society 7 (2006): 266-314.

${ }^{\text {iv }}$ Susan B. Carter, et. al., Historical Statistics of the United States. Earliest Times to the Present. Millennial

Edition (Cambridge, 2006), 1: 667; 4: 1027.

${ }^{v}$ Douglas Gomery, A History of Broadcasting in the United States (Malden, MA, 2008), 14.

${ }^{v i}$ Susan Smulyan, Selling Radio. The Commercialisation of American Broadcasting 1920-1934 (Washignton

D.C., 1994), 14 \& 39.

vii Hilmes, Radio Voices, 44-51.

viii Hilmes, Radio Voices, 63-64; Smulyan, Selling Radio, 104-8.

ix Alan Douglas, Radio Manufacturers of the 1920's (New York, 1989 \& 1991), 1: 67.

${ }^{x}$ Circular to RCA Distributors and Dealers from J.L. Ray, Sales Manager, 18 April 1928 Clark collection 55, 108/2, Smithsonian, Lemelson Center Archives [hereafter Smithsonian, Clark].

${ }^{x i}$ David Landes, The Unbound Prometheus: Technological Change and Industrial Development in Western Europe from 1750 to the Present (Cambridge, 1969), 428.

xii Clayton R. Koppes, "The Social Destiny of the Radio. Hope and Disillusionment in the 1920's," South Atlantic Quarterly, 68 (1969): 363-376; Smulyan, Selling Radio, 12-31; Thomas Eoyang, “An Economic Study of the Radio Industry in the United States of America" (PhD thesis, Columbia University, 1936), 72.

xiii "What does the public want," Radio Retailing (October 1929): 51.

xiv Gary Gereffi, "A Commodity Chains Framework for Analysing Global Industries," in Institute of

Development Studies, Background Notes for Workshop on Spreading the Gains from Globalisation (1999), 1-2, www.ids.ac.uk/ids/global/conf/wkscf.html

${ }^{x v}$ Raphael Kaplinsky, "Globalisation and Unequalisation: What can be Learned from Value Chain Analysis?"

Journal of Development Studies, 37 (2000): 117-46.

${ }^{x v i}$ Richard S. Tedlow, New and Improved. The Story of Mass Marketing in America (Oxford, 1990), 358.

xvii Sally Clarke, "Closing the Deal: GM's Marketing Dilemma and its Franchised Dealers, 1921-41," Business

History, 45 (2003): 60-79. For Ford before 1920, see Tedlow, New and Improved, 143-6.

xviii Clarke, "Closing the Deal;" Tedlow, New and Improved, 155-164.

xix Robert Sobel, RCA (New York, 1986), 21-35 \& 84; William Rupert Maclaurin, Invention \& Innovation in the Radio Industry (New York, 1949), 107-18; Leonard S. Reich, "Research, Patents, and the Struggle to Control Radio: A Study of Big Business and the Uses of Industrial Research," Business History Review, 51 (1977): 208235.

xx Maclaurin, Invention \& Innovation, 146.

xxi The histories of around 70 of the largest firms are summarised in Alan Douglas, Radio Manufacturers of the 1920 's. 3 vols. (New York, 1989 \& 1991).

xxii Caroline Manning, "Fluctuations of Employment in the Radio Industry," Bulletin of the Women's Bureau No. 83 (Washington, 1931): 32.

xxiii Peter Scott, "When Innovation becomes Inefficient: Re-examining Britain's Radio Industry," Business

History Review, 88 (2014): 497-521.

xxiv Manning, "Fluctuations of Employment in the Radio Industry:" 4-8.

xxv Martha L. Olney, Buy Now, Pay Later. Advertising, Credit, and Consumer Durables in the 1920s (Chapel

Hill, NC, 1991), 119-30; Walter A. Friedman, Birth of a Salesman. The Transformation of Selling in America

(Cambridge, Mass., 2004), 209-224.

xxvi See Scott, "When Innovation becomes Inefficient".

xxvii See Jean Tirole, The Theory of Industrial Organisation (Cambridge, Mass., 1988), 177-179.

xxviii "The Relation of the Jobber to Radio," article by David Sarnoff for Jobbers Salesman, 14 April 1923, in

David Sarnoff Technical Library, Publicity, Box 1, File B1F20, Hagley Museum Library [hereafter Hagley,

Sarnoff]. For details of Sarnoff's life and work see Sopel, $R C A$.

xxix "Radio and the Electrical Dealer" draft article by David Sarnoff for Journal of Electricity, 16 April 1923, in

Publicity, Box 1, File B1F20, Hagley, Sarnoff.

xxx "Radio," informal address by David Sarnoff, before Electrical Supply Jobbers Association, 26 May 1922,

Publicity, Box 1, Folder BIF 8, Hagley, Sarnoff.

xxxi Robert C. Planck, "Her Ladyship, the Radio Customer," The Radio Dealer (October 1925): 155-156.

xxxii Ibid.

xxxiii U.S. Department of Commerce, Merchandising Problems of Radio Retailers in 1930 (Washington DC, 1931), 8-9. 
xxxiv Friedman, Birth of a Salesman, 195 \& 202-3.

${ }^{\mathrm{xxxv}}$ Harold N. Cones and John H. Bryant, Zenith Radio. The Early Years 1919-1935 (Atglen PA, 1997), 92;

Crosley Radio Weekly (12 October 1925), 3, http://www.crosleyradios.com/pdf/CRW_October_12_1925.pdf; store advertisement, Spokane Daily Chronicle (11 th Oct. 1928), 13,

http://news.google.com/newspapers?nid=1338\&dat=19281011\&id=Q8tXAAAAIBAJ\&sjid=rPQDAAAAIBAJ \&pg=5617,2460983.

xxxvi RCA Victor, "Merchandising Policy of the Radiola Division for the Year 1930-1931," 24 July 1930. RCA

Victor Camden/Frederick O. Barnum III collection, 2069/9/38, Hagley Museum Library [hereafter Hagley,

RCA Victor].

xxxvii Eoyang, "An Economic Study of the Radio Industry," 137.

xxxviii Circular from E.E. Bucher, General Sales Manager, RCA, to authorised Radiola Dealers, 18 Jan. 1926,

Smithsonian, Clark 55, 239/1.

xxxix RCA Sales Dept. Retail Dealers Discount Schedules, Smithsonian, Clark 55, box 97; M.B. Sleeper,

"Distributing problems of radio manufacturers," Wireless World and Radio Review (23 Dec. 1922), reprinted in Douglas, Radio Manufacturers of the 1920's, 1: viii.

${ }^{\mathrm{xl}}$ RCA Sales Dept. Retail Dealers Discount Schedules, Smithsonian, Clark 55, box 97.

xli Circular from E.A. Nicholas, Manager, Radiola Division, RCA, to RCA Radiola Distributors, $3^{\text {rd }}$ Dec. 1928, Smithsonian, Clark 55, 108/2.

xlii Speech by Paul Klugh to annual meeting of Zenith stockholders, 25 June 1930, cited in Cones and Bryant, Zenith Radio, 92.

xliii Alfred D. Chandler, Strategy and Structure. Chapters in the History of the Industrial Enterprise (Cambridge, Mass., 1962), 145-53.

xliv Cones and Bryant, Zenith Radio, 25.

xlv Circular to RCA Victor distributors by Roy A. Forbes, 15 October 1930, Hagley, RCA Victor, 2069/9/41.

xlvi "RCA Victor Production Control and Requisition Plan," 1 July 1931, Hagley, RCA Victor, 2069/9/41.

xlvii "Seasonal Trend. RCA Radio Sets and Phonographs," RCA Victor memorandum, signed "BLA", $15^{\text {th }}$ Feb.

1943, Hagley, RCA Victor, 2069/9/47.

xlviii Letter, "BLA" to "Tom", 6 April 1943, Hagley, RCA Victor 2069/9/47; Clarke, "Closing the deal," 62-63.

xlix Some surviving copies are available at http://www.crosleyradios.com.

${ }^{1}$ Neil H. Borden, The Economic Effects of Advertising (Chicago, Ill, 1942), 404-6.

${ }^{\text {li }}$ Memorandum to all RCA Radiola Distributors, 9 Oct. 1929, Smithsonian, Clark 55, Box 97.

lii Crosley Broadcaster, $1^{\text {st }}$ November 1928, 13.

liii "RCA Victor Company Inc. Co-operative Advertising Plan, Oct $1^{\text {st }}$ to Dec. 31, 1931," circular, c. September 1931, Hagley, RCA Victor, 2069/10/14.

liv "Special Discount and Cooperative Advertising Plan for Large Accounts, season 1931-32," (n.d., c.

September 1931), Hagley, RCA Victor, 2069/10/14.

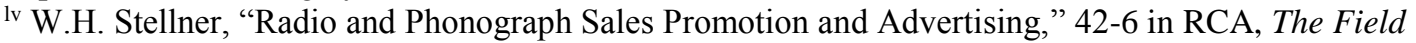

Representative's training course 1935-36” (1935), 42-4, Hagley, RCA Victor, 2069/10/5; RCA memorandum to all RCA Radiola Distributors, 9 Oct. 1929, Smithsonian, Clark 55, Box 97.

lvi Minutes of Deforest Interdepartmental Committee, 28 May 1925, Smithsonian, Clark 55, 104/4,; "Course in Radio Salesmanship and Service. Manual or Discussion Meetings," De Forest Radio Institute (n.d., 1920s),

Smithsonian, Clark 55, 110/3.

lvii RCA circular to all RCA Radiola distributors, 8 Jan. 1927, Smithsonian, Clark 55, Box 97.

lviii New York Times, $14^{\text {th }}$ February 1926, cited in Leslie J. Page Jr., "The Nature of the Broadcast Receiver and its Market in the United States from 1922 to 1927," 467-72 in Lawrence W. Lichty and Malachi C. Topping,

American Broadcasting. A Source Book on the History of Radio and Television (New York, 1975), 470.

lix National Electrical Manufacturers Association, The Radio Market (New York, 1928), 3.

${ }^{1 x}$ U.S. Dept. of Commerce, Bureau of Foreign and Domestic Commerce, "Merchandise Problems of Radio

Retailers in 1930," Travel Information Bulletin No. 778 (Washington D.C., 1931), 4-5.

lxi R.H. Langley, "Radio Developments in 1934. Part IV - A Review of Radio Broadcast Reception During 1934," Proceedings of the Institute of Radio Engineers, 23 (1935): 433-441.

lxii U.S. Dept. of Commerce, Bureau of Foreign and Domestic Commerce, "Merchandise Problems of Radio Retailers in 1930," Travel Information Bulletin No. 778 (Washington, 1931 ), 7.

lxiii 'Your Sales Program for 1929,' Radio Retailing (February 1929): 36-7.

lxiv The earliest estimate, for 1927, indicates that new sets required around six tubes, "Broadcast: Published for the Radio Industry. An Analysis of the Radio Market," leaflet, presumably included with a copy of the trade magazine Radio Broadcast, no date, c. 1929, Smithsonian, Clark 55, 207/3.

lxv “The RCA-C.I.T. Finance Plan," 10 Sept. 1928, Smithsonian, Clark 55, 103/3; Friedman, Birth of a Salesman, 196-7. 
Ixvi U.S. Dept. of Commerce, Bureau of Foreign and Domestic Commerce, "Merchandise Problems of Radio Retailers in 1930," Travel Information Bulletin No. 778 (Washington, 1931), 12.

lxvii “"The RCA-C.I.T. Finance Plan”, 10 Sept. 1928, Smithsonian, Clark 55, 103/3.

lxviii Martha Olney, "Credit as a Production-Smoothing Device: The Case of Automobiles, 1913-1938," Journal of Economic History, 49 (1989): 377-91.

lxix Ibid.: 388-390.

lxx “Finance Companies Re-enter the Field,” Radio Retailing (October 1935): 20.

lxxi Powel Crossley Jr., "Ten Commandments to 16,000 dealers," The Radio Dealer (April 1926): 52-3.

lxxii Harold Barger, Distribution's Place in the American Economy since 1869 (Princeton, 1955); 32; Borden, Economic Effects of Advertising, 402-3.; Eureka Co. adverts in the Saturday Evening Post, March $9^{\text {th }} 1912$ and 1914, in Eureka Williams Electrolux archive, Box 3, McLean County Museum of History, Bloomington Illinois. lxxiii Frank H. Williams, "How they Sell Radio by House-to-House Solicitation," Radio Merchandising (Dec. 1924), 13-16.

lxxiv H.U. Mann, "Selling in the Home Multiplies Desire," Radio Retailing (May 1930): $22-4$.

lxxv “Does House-to-House Selling Really Pay?" Radio Merchandising (July 1925): 57-58.

Ixxvi J.J. Moore, "How Radio is Sold in the Greatest Southern Store," Radio Merchandising (August 1925): 17-

19.

lxxvii “Your Sales Program for 1929," Radio Retailing (February 1929): 36-7.

lxxviii The Crosley Broadcaster (1 Feb. 1929); 5.

lxxix R.A. Fobes, "Building," Victor Talking Machine Division, memorandum (n.d., c. 1928); "The Victor Resale Plan," (n.d., c. 1928), Hagley, RCA Victor, 2069/9/36.

${ }^{1 x \times x}$ U.S. Dept. of Commerce, Bureau of Foreign and Domestic Commerce, "Merchandise Problems of Radio Retailers in 1930," 8.

Ixxxi R.A. Fobes, "Building," Victor Talking Machine Division memorandum (n.d., c. 1928), Hagley, RCA

Victor 2069/9/36

Ixxxii “The Victor Resale Plan,” (n.d., c. 1928), Hagley, RCA Victor 2069/9/36.

Ixxxiii “'Speciality selling' - the answer to sales slumps," Radio Retailing (March 1929): 44-6.

Ixxxiv S. J. Ryan, "109 Radio Merchants Answer the Question - What of Selling Costs," Radio Retailing (Sept. 1929): 52-4 \& 92.

lxxxv W.W. MacDonald, "4 Years in Business and Never Pushed a Doorbell," Radio Retailing (June 1934): 14-15 $\& 25$.

Ixxxvi Henry W. Baukat, "It's a Sale - Not a Demonstration!," Radio Retailing (March 1930): 18-19 \& 58.

lxxxvii “'It Costs \$13.43 for Every Home Demonstration that Doesn't 'Jell'," Radio Retailing (March 1930): 45.

lxxxviii S.J. Ryan, 'Expenses, 29.5\%, Profit, 8.2\%. Part II of Radio Retailing's Co-operative Industry Survey of the Costs of Selling Radio,' Radio Retailing (October 1929): 56-60 \& 96. This was undertaken in conjunction with the Federated Radio Trade Association and the National Association of Music Merchants.

lxxxix Ryan, "109 Radio Merchants Answer the Question". The dealers whose returns were tabulated had sales ranging from $\$ 900$ to $\$ 40,000$ and totalling $\$ 7.2$ million. There was some bias towards larger firms (who would be in a better position to produce the necessary accounting data). Their average net sales of $\$ 66,184$ are higher than Census averages for 1929 ( $\$ 52,769$ for radio and musical instrument stores and $\$ 28,625$ for radio and electrical shops; or $\$ 35,030$ for both). U.S. Department of Commerce, Fifteenth Census of the United States: 1930. Distribution. Volume 1: Retail Distribution (Washington D.C., 1933), 48.

${ }^{x c}$ Ryan, "Expenses, $29.5 \%$, Profit, 8.2\%".

xci Survey schedule, published in Radio Retailing (July 1929): 83. Occupancy included rent, light, heat, water, etc. Where the property was owned by the retailer, a notional rent was estimated, based on 6 per cent of the cost of land and buildings, together with depreciation at 2.5 per cent of building costs. Selling expense involved the costs of the sales force, selling-related stationary, other miscellaneous selling expenses, delivery (including depreciation on equipment at $40 \%$ of cost); and demonstration expenses. Publicity included advertising, circulars, and window dressing. Gross Margins were found to be substantially smaller than the discounts from selling prices received by retailers - reduced by trade-in's; sets sold at below original list prices (including obsolescing stock or, occasionally, stock where the manufacturer had cut the list price); and by breakages and returns.

xcii Of the 109 firms in the full sample, seven do not have information on publicity expenditure and one has no information on occupancy.

xciii One caveat with this methodology is that higher profits may impact on promotional expenditures. This endogeneity issue is not accounted for and may lead to estimates that are biased upward, (Richard Schmalensee, The Economics of Advertising (Amsterdam, 1972), 98-100). As the data are cross-sectional, we cannot use the typical approach to resolving this - instrumental variable methods with time lags and other exogenous variables - as there are no candidates for instruments. However, we do not consider this to be problematic in our case. We 
examine the relative impact of promotional and selling expenses, so if higher profits lead to higher expenditures, it would seem likely they would do so for both promotion and selling. Furthermore, as our findings show large and very well determined differentials between the two forms of sales promotion, the extent of bias would need to be extremely large. Previous studies suggest a relatively modest bias, in the context of well-determined results - Peter Scott and James T. Walker, "Advertising, Promotion, and the Competitive Advantage of Interwar UK Department Stores”, Economic History Review, 63 (2010): 1105-1128; Peter Scott and James T. Walker, "Returns to Advertising Expenditure for Interwar American Department Stores," Journal of Economic History 71 (2011): 33-59; Matthias Greuger, David Kamerschen and Paul Klein, "The Competitive Effects of Advertising in the US Automobile Industry, 1970-94," International Journal of the Economics of Business 7 (2000): 245-261; John E., Kwoka, Jr, "The Sales and Competitive Effects of Styling and Advertising Practices in the U.S. Auto Industry," Review of Economics and Statistics 75 (1993): 649- 56.

xciv Sources: Radio output - S.B. Carter, et. al., Historical Statistics of the United States, 1: 667; 4: 1027. Store data, U.S. Dept. of Commerce, Bureau of the Census, Sixteenth Census of the United States: 1940. Census of Business Volume 1. Retail Trade: 1939 (Washington, 1943): 57.

${ }^{x c v}$ Rajesh K. Chandy and Gerard J. Tellis, "Organising for Radical Product Innovation: the Overlooked Role of Willingness to Cannibalize," Journal of Marketing Research, XXXV (1998): 474-487; Alfred D. Chandler, Inventing the Electronic Century (New York, 2001), 133-135.

xcvi Chandy and Tellis, "Organising for Radical Product Innovation."

xcvii Claudio Giachetti and Gianluca Marchi, "Evolution of Firms' Product Strategy over the Life Cycle of Technology-based Industries: A Case Study of the Global Mobile Phone Industry, 1980-2009," Business

History, 57 (2010): 1123-1150; Michael L. Tushman and Philip Anderson, "Technological Discontinuities and Competitive Environments," Administrative Science Quarterly, 31 (1986): 439-465.

xcviii Maclaurin, Invention and Innovation, 137-148.

xcix Ibid, 148-149.

${ }^{\mathrm{c}}$ Emerson Radio and Phonograph Co., Small Radio. Yesterday and in the World of Tomorrow (New York, 1943), 28-30.

ci "Midgets hit the East," Radio Retailing (August 1930): 56-7 \& 65.

cii Peter L. Jensen, “A New Major Development in Radio,” Radio Industries (July - August 1933): 56.

ciii Emerson Radio and Phonograph Co., Small Radio, 34-36.

${ }^{\text {civ }}$ Maclaurin Invention and Innovation, 148. Crosley survived the Depression, but on a much reduced scale.

cv "Midgets hit the East."

cvi See Scott, "When Innovation becomes Inefficient."

cvii See Jonathan Rees, Refrigeration Nation. A History of Ice, Appliances, and Enterprise in America (Baltimore, 2013), 141-161; Robert Hoover and John Hoover, An American Quality Legend. How Matag Saved Our Moms, Vexed the Competition, and Presaged America's Quality Revolution (New York, 1993), 105-172. cviii See Steven Klepper, "Industry Life Cycles," Industrial and Corporate Change, 6 (1997): 145-181. cix Tushman and Anderson, "Evolution".

cx These were available to all firms, with a short lag, owing to the industry's patent pool agreements; Sobel, RCA, 84-108; Maclauren, Invention \& Innovation, 132-36.

cxi Giachetti and Marchi, "Evolution of Firms' Product Strategy;" Steven Klepper and Peter Thompson, "Submarkets and the Evolution of Market Share," Rand Journal of Economics, 37 (2006): 861-886.

cxii See Tushman and Anderson, "Evolution". 